\title{
The Portrait of Women Resistance towards Patriarchy System in the Movie of Dilema Ijab Kabul
}

\author{
Suhadi $1 \bowtie$ \\ ${ }^{1}$ Sociology Teacher of SMA N 1 Pamotan, Rembang, Central Java, Indonesia \\ Permalink/DOI: http://dx.doi.org/10.15294/komunitas.v7i2.3601 \\ Received : August 2015; Accepted: September 2015; Published: September 2015
}

\begin{abstract}
This paper aims to interpret the women resistance towards the patriarchy system on a documentary film entitled "Dilema Ijab Kabul". The focus of the documentary film analysis which portrays the behavior of early marriage is to be the earliest mapping in explaining that the action the women take is really as an opposition or vice versa. The concept used in analyzing the resistance of women against patrialkhal system in this documentary was the concept of the meaning of each daily interactions in society, women's position, and orientation in a relation to men and women. Based on the finding, the analysis result of this documentary movie tries to invite the audience to see the wedding of the social phenomenon that is very different from the usual. Marriage is shown by a hegemony which then leads to a form of resistance from the women. Resistance to the patriarchy system which is done by women in the documentary movie is seen from many phenomenon of early marriage, divorce, and re-marry.
\end{abstract}

Keywords: female resistance; patriarchy hegemony; marriage

\section{INTRODUCTION}

According to Tong (1998), feminist movement has a tendency to go against the hegemony of the patriarchy social system. The purpose of the women's movement over the other is not to criticize the throwback era but, with the women role emancipation in the development without seeing the gender. In achieving the above objectives, many feminist movements have raised to the surface (Edgar 2006; Ghodsee 2012; De Haas and Van Rooij 2010). Indonesia has national figures like Kartini, Roehanna Koedus, and Dewi Sartika, can be included as a pioneer of the women emancipation movement in Indonesia. But, according to Suhadi (2010) the movement has impressed as an individual movement which is not institutionalized and not organized systematically, so it ends in the middle of the street. However, feminists seem not desperate to spur the feminist movement in order to achieve the development emancipation.
The change in the interpretation against the patriarchy systems has produced a new phase in the movement against the patriarchy such as a feminists industry which survives from the law of social evolution. Movie product which has theme of women against the patriarchy systems has become a turning point in the struggle of the feminist followers. This article gives an important addition to the still limited work on feminist struggle through media by exploring an example in Indonesian context (Edgar 2006; Ghodsee 2012; Razack 2004; Moghadam 2004).

Although relatively little representation of women in the film (BBC 2014), at least there are some movie products that can be positioned as the center of movement in fending marginalization of women in the development. The title of the movies including; Get Married, Jamila dan Sang Presiden, Inayah, Ca Bau Kan, Berbagi Suami, dan Arisan. Several researchers have studied the

\footnotetext{
Corresponding author :

Address: Rembang, Central Java, Indonesia

Email : suhadi@gmail.com
}

Telp (c) 2015 Semarang State University. All rights reserved p-ISSN 2086 - 5465 | e-ISSN 2460-7320

\section{UNNDS JOURNRLS}


slick on the position of women in the film.

Muslim (2009) in his study examines the meaning of the marriage behind the visualization and dialogue in the film Get Married. With the approach of Roland Barthes semiotic interpretation, Muslims finds three meanings in the film of this marriage: first, the marriage industry like ethics and moral individual as the successor generation, second, marriage as a cover of family disgrace, third, marriage as a form of compulsion parents. From the study, it looks for inconsistencies marriage function played by women. But Muslims have not been deep enough in his study whether this inconsistency marriage function has a relationship with the resistance movement feminist or not (Mir-Hosseini 2006; Razack 2004; Smith-Hefner 2005).

If the Get Married movie describes the inconsistency of women's role in the institution of a new family, the similar finding is also reported by Ghassani (2010) about the role of women who appear in the film Jami$l a$ and the President. The study conducted by Ghassani using socialist feminist theory and feminist attitude (standpoint theory) has managed to construct with a slick about how the representation of the violence towards women.

In the Jamila dan Sang Presiden movies, Ghassani finds some vulgar scenes involving physical violence, sexual, economic, deprivation of the women freedom and psychological of the women. In this movie, women go against the act of killing the perpetrators of the violence. But the end of the resistance of the women in this movie, has been completed with the showing resistance foundered in the end. Again, Get Married and Jamila dan Sang President have confirmed that the oppression of women only as a trigger for the feminist audience, but the masculinity has become the dominant point of view in the groove of display.

The movement glorifying women in development does not stop at the production of movies with contemporary thematic. Home production movie entitled Inayah that could reap high rating on private television has realized the system related to the role of women in certain religious institutions. Prismadani's study (2011) tries to ask again about the myth of women in polygamous families in the soap opera, Inayah. By using the paradigmatic and syntagmatic analysis developed by Saussure and Roland Barthes, Prismadani believes that the allegations of the film basically does not reproduce, but instead determine (to define) the reality through the use of words that are chosen. Ghassani proven in studies, women in the film constructed social roles as wives, mothers, and housewives who have never given a chance to be angry when suppressed in a family. While the idealization of the social role of men as head of the family, and the financial resources have become dominant and stay ahead and legalize the construction of masculinity carrying the viewers as well. An appealing lawsuit of the Inayah film, where women have been exploited in a polygamous family. But the end of the film is merely presenting a false empathy to women, while men remain commander. Inayah the film also seems to have reproduced the thematic at home soap opera newcomers, Catatan Hati Seorang Istri (CHSI) newly aired since June 9, 2014 to the present on the national television station recently (Wikipedia, 2014). Soap opera with full drama of the story of being husband and wife which is full of conflicts has top three rating report with 4.0 TVR and $16.1 \%$ share of the category of the soap opera that is always awaited by viewers slot (Anonymous 2014).

The next movie is the movie by Nia Dinata, a feminist woman director. Ca Bau Kan, Berbagi Suami, Arisan, and Perempuan Punya Cerita Segmen Perempuan dari Cibinong, the films are loaded with liberal feminist movement. With the critical discourse analysis belongs to Sara Mills, Surwati (2011) studies to find out how strong feminist movement in the films by women directors. Three important things that Surwati finds that women have a chance to improve their careers, women have rights in sexual matters, and women have the right to determine the future.

If the study of the previous films invite the audience is aware of the cliché in 
the women's position and have the effect of turning against the women's movement by themselves, but in the film by Nia Dinata is quite firmly that such films play a role in constructing feminism is accidentally produced and circulated in the era of diversification of feminism. After the Surwati study, there has been no follow-up study on the degree of change in the feminist audience after watching the film were quite bold and challenging.

There are two important things that can be learned from the study of the films above. First, the women's movement against the patriarchy system only limit the awareness of the women in marginalized position (Moghadam 2004; Hunnicutt 2009; Salhi 2010). But in the same round, the movies are presented instead become a turning point in attacking the feminist, it is to construct that women should obey to the masculinity power system. It can be seen from the Ghassani findings (2009) concerning the inconsistency marriage function played by women and Prismadani (2010) about the women in violent resistance inconsistency shown by the winners. Surwati (2011) there are some movies about the exploitation of the women in polygamous families. Second, women in the struggle against the patriarchy system use the vulgar movies. Resistance movement is the evident in the Surwati study (2011) where the women as a feminism is diversified by media. Thus, the movement against the patriarchy system shown by the women in the films which are produced has two characters, namely timid motions are susceptible to the interpretation that at any moment ready to obey and against the women's movement, and the movement of the characters firmly in breaking down the walls of the patriarchy system. And, how about the women's movement against the patriarchy system on the documentary film "Dilema Ijab Kabul"?

Determine the resistance of women against the patriarchy system in the above films is done by answering some questions as follows: (1), what is the function of an arranged marriage, early marriage, divorce, remarried?; (2), in that condition, does the position of women in a state of harmony and balance to much of the desire to fight the patriarchy system?; (3) what is the interests and power of the phenomenon of arranged marriage, early marriage, divorce, remarried?; (4) in that condition, does the position and pattern of female relationships changed?; (5) do marriage and divorce use the symbols in their social interactions?; (6) How does the interaction model is used in the process of marriage and divorce?; (7) what is the meaning which is owned in the marriage and divorce?; and (8) what is the definition which is used in the marriage and divorce in this patriarchy system? The instruments above are used to map the resistance of women towards patriarchy system. Whether the mapping results really as a resistance, or the opposite, this is the focus of this paper.

\section{RESEARCH METHODS}

To find out how does the women's movement against the patriarchy system in the documentary film "Dilema Ijab Kabul", this research used narrative film as the primary data in this research. Furthermore, in the narrative documentary "Dilema Ijab Kabul" was classified into six parts. The six narratives were; the social construction of narratives about the age of a marriage, marriage meaning, matchmaking procedure, the dominant role in the wedding process, the resistance of the women, and the narrative that contains collective reflection of young widows to the wedding traditions.

The analysis technique used in this research was the content analysis approach. According to Earl Babbie and Harold Lasswell (in Suhadi 2010, p.54-45) and Neuendorf (2002) the content analysis approach is to analyze the existing transcript of a taped interview in the film "Dilema Ijab Kabul". The soft copy was downloaded from the Eagle Documentary Series website which can be downloaded easily any time. In addition for using the soft copy film, also conducted in further interviews to the film director and his crew.

Furthermore, the results of the transcripts were then analyzed by sociological concepts which has been presented by 
Hanslin (2006) with the three basic devices instrument. The first instrument about the functional analysis which focuses on the structure, functions (manifest-latent), dysfunction, and equilibrium. Second instrument about the symbolic interactionism perspective which emphasizes the use of symbols, interaction, meaning, and definition. The third instrument about the conflict perspective which focuses on the inequality, power, conflict, competition, and exploitation. The conceptual basis above have ever used by Fakih (2010) and Suhadi (2012) attempt to unravel the meaning of each daily interactions in the society, women's position and the orientation in the relation to men and women.

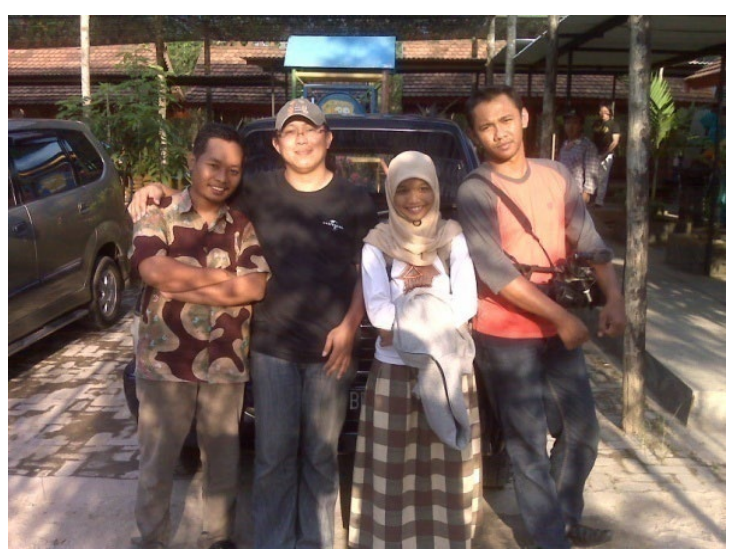

Picture 1. Photo after interviewing the film director, Hadi Marlan (in a hat) and the crew of Dilema Ijab Kabul film (Source: Dok. Suhadi, 18 August 2013).

\section{RESULTS AND DISCUSSION}

The documentary film entitled "Dilema Ijab Kabul" is the creation of young filmmakers in the Eagle Awards 2013 with the theme "Harmoni Indonesia" which is organized by the Eagle Institute. The film which is directed by Hadi Marlan has aired twice on the national television on March 8 and 10 in November 2013 at 23:05 pm and at 13:05 pm.

This film depicts the social life on the slope of the mountain. Social phenomenon raised in this film is a tradition in the community, marrying their children withing under age marriage. An interesting culture in the documentary film is when there is a social culture in the farmers habitation on the slope of the mountain which leads them to the experience of social psychological shock. Psychological shock is shown by the behavior of the girl's parents in a pressure, fear, and feel anxious when there is no man who wants to propose their daughters.

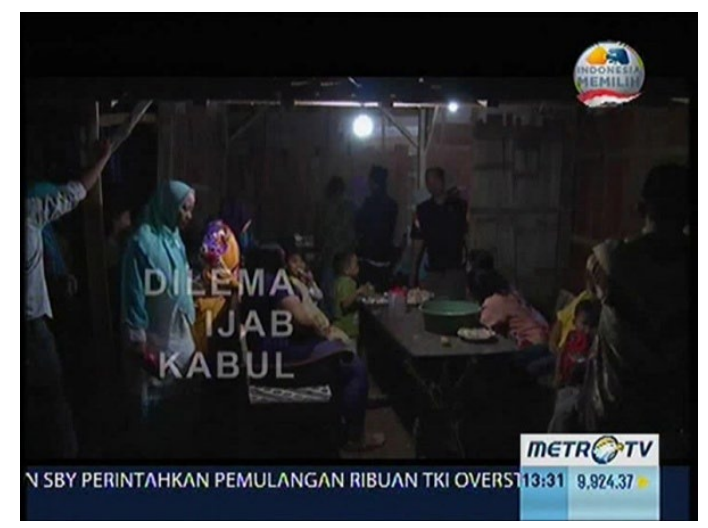

Picture 2. The cover scene of documentary film Dilema Ijab Kabul has aired twice on Metrotv.

The parents have to show themselves as the absolute holder of the power towards their daughters. Choosing a mate, the procedure for the wedding celebration, when and how its implementation, is a power manifestation of the parents to their children. Parents have the control of their children's marriage.

In this film, there is a debate about the meaning of a virgin woman with a widower. Interestingly, women with widow status are more respectable than those who are still virgin. The social construction of more respectable widows here, then have an impact on the number of widows in the young generation.

Getting married anytime and getting divorce at the end are common. Getting married in the morning then divorce in the afternoon is an easy thing. The important thing is the complete administration, all will be easy. The age of a marriage in this documentary is quite short. From one month, a week, even only lasted one day and one night, can be found in this film. Wedding procession was as a pretense, not a sacred event that should be maintained. They are not shy to divorce and remarried. 
Two interesting things in this documentary, besides being able to present a unique social reality of a marriage and divorce, the film is also able to answer why it happened. Married, divorced, and remarried are instrumental rational social action.

This film by actively encouraging the viewers to understand broadly about the meaning of a marriage and divorce. It can be seen from the description of the resource in this film, where there is an economic transactions between the families of the groom and bride. The economic transactions shown in the application by bringing food and valuable things. Buffalo, snacks, gold valued at millions rupiah, has become a mandatory luggage when the ijab kabul is conducted. After the short marriage soon, they divorce their children, it is profitable for the parents. It is indeed dilema ijab kabul in the marriage.

First Narrative:

"here, a woman who is 16 year-old or more than that, neighbours will say " perawan kasep or ora payu rabi." It is better being a widow than an old virgin ". (01.05- 01.25 on the first video)

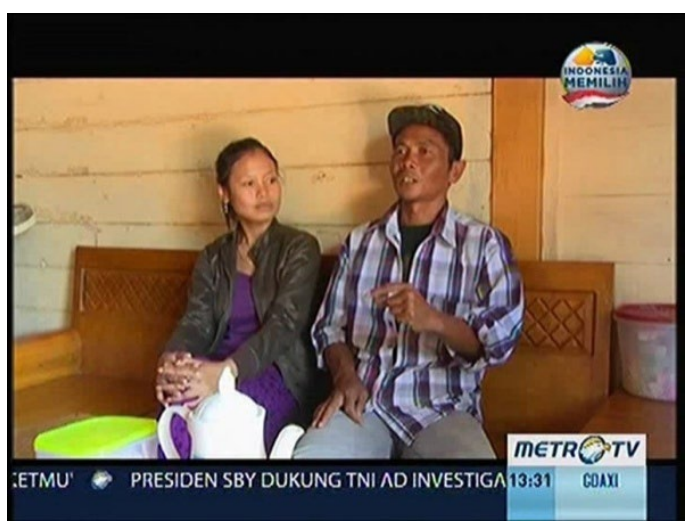

Picture 3. Tormen and his wife told the story about the age of a marriage and the perception of when is the proper age of marriage on the scene film "Dilema Ijab Kabul."

The narrative above is a social construction about when the women should get married. In the narrative states that the women who marry before 16 year-old, is good. The opposite, if the women marry at the age over 16 years, is not good. The construction can be studied on the use of the word virgin, $k a-$ sep and still virgin at the old age.

The word "kasep" and old in the narrative above have been equated with the virginity. The word meaning of virginity itself indicates the purity, chastity, and cleanliness. Thus the message of the narrative above are purity, chastity, and cleanliness which have become the former and useless. The statement above expressed by men indicate that men have the power to redefine the meaning of the symbolic virgin who originally are purity, chastity, and cleanliness into something full of falsehood.

Why does the patriarchy social system in the form redefine the meaning of virginity through the marriage? The limitation age which is used in the glory of women is an element in the social structure which can not be separated in a universal social system. Through the redefinition of the glory of women, women will always be in the control of the men power whenever and wherever they are.

Through the redefinition above, women are really stuck in the meaning of the game. The meaning itself then, operate like a machine that the steps have been made to reproduce the power of the men over the women. Here are the game's manifest function of the position of women which are expected by men. Women have been served as a social menu to be consumed by the men.

The statement "it is better to be a widow than the old virgin" and then continue the emitting latent functions where the women collectively will have the same view, namely the sanctity handed to men whose the age has been far in front. The last function of the meaning above is to maintain the equilibrium of patriarchy social structures. Women hegemony towards men will always be protected from the pseudo meaning of women who are ready to crush the resistance in the future. However, the weapons possessed by the patriarchy social adherents could happen behind the opposition of his own people or from the target object.

To maintain the harmony function of the trap meaning that "a virgin should not be kasep" and "perawan kasep alias ora payu 
rabbi" are a conflict spaces that were built by men. The women have been provided the conflict spaces that never against men. It can be seen from the life orientation to get married (rabbi).

The intention to get married is the women compete with other women in getting men as partners. The women are contradictory and competing with other women to get a partner. The main conflict in the internal status of women is let the chosen men take their virginity. That's when the exploitation occurs in women themselves to immediately sacrifice themselves in order to get the glory in the patriarchy social system.

\section{Second Narrative:}

"everyday I can have many wedding celebrations until o1.0o a.m. or 02.00 a.m. is common here. It can be 6 people in a day. So, maybe it can be said that the parents here want their children to get married as soon as posible, "pengen andri gawe, duwe kajat, ben di sumbang karo tangga teparo." ( $03.02-04.18$ on the first video)

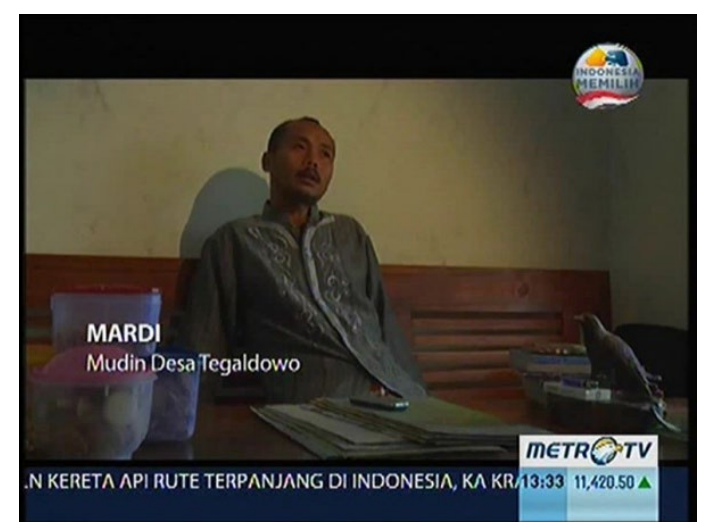

Gambar 4. Modin Mardi told his experiences being a marriage registrar on the film scene "Dilema Ijab Kabul"

The meaning of marriage in the above narrative has been widespread. Starting from the sacred braided ties, widens into a space that exceeds the value of the exchange transaction. In a day, a muezzin and the headman are able to mengijab-kabulkan six bride couples. In the same day, the community has to contribute in the wedding celebration event.

The meaning expansion of the wed- ding celebration into the entrance in encouraging the possession turnover. Wedding celebration has synergize the wedding service structure functions of the government with a devoid social structure of jobs vacancy. The waiters always taste the another income of the wedding celebration besides the main income. The owners also get a wedding donations to be used in the next celebration.

Family has to realize that the donation is plentiful; it must be in a position ready to be swept away in eddies discordant-contributed from recurring wedding celebration procession. It has become a system of socioeconomic balance on the mountain slope which is very limited the complexity of the job option. Wedding procession streak and repeated the answer as an adaptation pattern between the limited ecological economics and the tradition. A tradition that has spread in the economic institutions, usually have a fairly high level of reliability.

A muezzin who accompanies the headman has been the key figure to marry and divorce the bride and groom who will be married. The power of bride's family has become critical. The more power, the family immediately do the ijab kabul. In contrary, the couples who are divorced in the ijab $\mathrm{ka}$ bul, as a sign of the bride's family has no power.

Power stage is also determined from whom and how many guests who attended the wedding celebration. More and more guests who will come, the social status is higher from the guests who come at the wedding, indicate that the family holding this event is respected. There is an exploitation of the wedding procession.

\section{Third Narrative:}

"Parents are able to find high quality groom. For better future and the economic condition will be good. But, in reality, there are many couples who divorce"

$$
\text { ( } 04.07-04.18 \text { on the first video) }
$$

"being a widow here is not a disgrace, it's become an honor. "Ohhh, anakkku wis payu, hehehe." That's happen here. Therefore, there are many under age widows 
here. So many here, in Tegaldowo, it's not a disgrace". (05.23 - 05.39 on the first video)

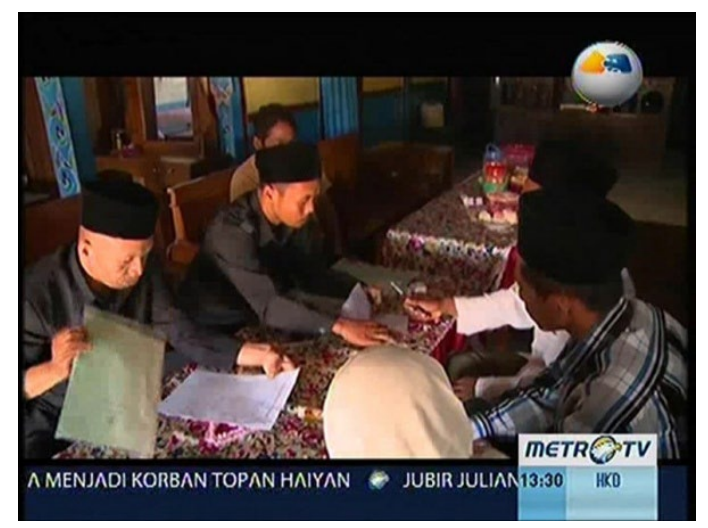

Picture 5. Modin Mardi helped the ijab kabul procession on the film scene "Dilema Ijab Kabul”.

Find a mate is a step for the parents that their daughters will not enter the stage of a risk in the life. However, this step does not involve their daughters. The position of girls in the zero state without any option and rejection. Obey the wishes of the parents is a concrete manifestation of a devotion and obedience.

"being a widow here is not a disgrace, it is an honor. "Ohhh, anakkku wis payu, hehehe. That is what happened here." Excerpts of this statement as a sign that the failure of parents to choose a suitable mate is not the fault of parents. Divorce is seen as a success of the parents in delivering their social status to be respected. It can be seen the symbol which is used in the measure of pride when their daughters become a widow. "being a widow here is not a disgrace" clearly indicates that the status of widow is originally known as a risk status, now change. The definition of a widow is a proud social status. As a social prestige, of course, the status of widow here has become an expectation of the parents.

Matchmaking model in the film $\mathrm{Di}$ lemma Ijab Kabul has an interesting matchmaking structure. Family that has good economic level, has a line of meeting a mate with a family that has good economic level. Matchmaking is a noble goal of the parents to prepare their children to enter the new family in the good economic level. But that hope has become disappear with the disappearance of these noble goals marked by the divorce. A complex chaos which is indicated by the purity of the marriage, but at the same time the couple divorce immediately. A complex chaos in the process of matchmaking, it seems to keep the hidden transcript. A society which produces these under age widows, has five interconnected elements in building the life balance by marriage and divorce. The five elements namely; proposal stage, followed by a wedding procession, the inclusion of a serious problem stage in a new family couple, and then divorce, until the stage of redefinition widow who is married the second time with the stages like the first wedding procession.

"Being a widow here is not a disgrace, it is an honor. "Ohhh, anakkku wis payu, hehehe. That is what happened here." The fragment of this statement, impressed the absence of the conflict in the procession of divorce. Divorce is not a disgrace, it does not break the rule. Pride after marriage also shows that divorce is a prestige which become an important element in determining the hierarchy on a social structure. Social conflict which is happened is the role of the parents power to compete in reaching the higher social level in the social structure. By forcing their daughter to be a widow, is a way to get a respectable position. There is difference about the things which affect the position and role in the social structure.

Fourth narrative:

"In 2006 I remembered there were 75 weddings and there were 37 who divorced. Here, married and then divorce, it only took one year for longer time but, it is rare. Sometimes they have only two months, one monyh, one week, a day, it is good enough.. Does not get along together, separated, there are so many. It is a common thing, does not feel shy, it is an honor, married again and again, "laris"'. (oo.44 - 01.33 on the second video) 


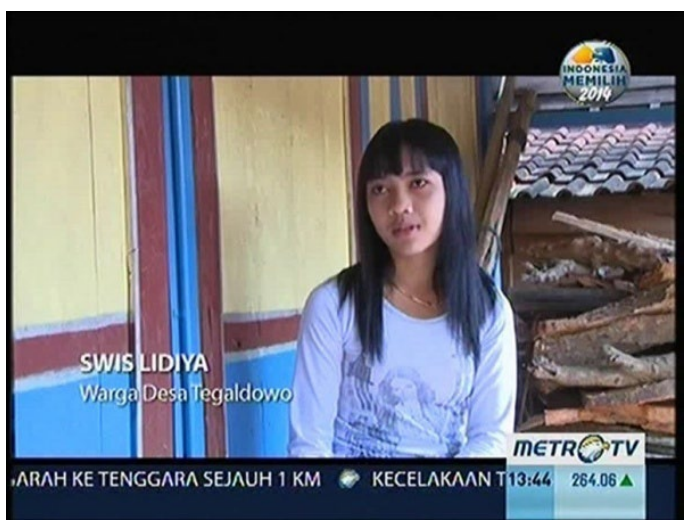

Picture 6. An under age widow who has been married three times on the film scene Dilema Ijab Kabul.

The narrative above has two stages in identifying a subject who has a dominant role in the wedding procession. In 2006, a Muezzin has helped the implementation of the wedding ceremony. But in the same year, he also accompanied to succeed the divorce.

Two stages are also played by the parents. Winning the competition for getting the bride for their daughter is not an easy thing. Various social capital which they have for getting bride at the same or higher level. But then, they approve of their daughter to divorce gracefully.

So it is with the bride. The marriage has been done in a good condition. The zero position of their daughters and their son-inlaw to be present in the ijab kabul, a sign of themselves and their families as an agreement to merge into one big family. But then, they no longer to speak each other. A divorce immediately happened a moment later. Between the ijab kabul and talak which can not be separated.

The divorce of 37 pairs from 75 pairs of marriage, have been a strong sign that the original purpose of marriage is not held with the basic foundation. Sacred ceremony to bind the women become wives and men become their husbands, proved can be broken. The ideal function of a wedding procession is not ideal. Thus, there are other functions in this sacred procession.

"There are only two months, one month, one week, a day, it is quite good. Do not get along together, and separated, there are many here ". The statement seemed to make the wedding procession is only a matter of releasing virginity. Furthermore, the widow status is laid on their both shoulders. So what is the concealed functions in the wedding ritual that produces these under age widows?

Several allegations from the previous narrative, the wedding orientation which is full of risks have the goal to accumulate the power and authority ownership of honor. If the orientation of the marriage only after the power of the social and economic structure, when the goal was met, then the wedding anniversary performances should not be done, but in reality it is not like that. Thus there is a hidden function on the perpetrators of the marriage. Things that should be delivered in answering this hidden function is the attitude and action of the girls against the power of their parents and their parents in-law as a symbol of women resistance against the patriarchy system which is bound the freedom of movement.

"Does not get along together, separated, there are so many. It is a common thing, does not feel shy, it is an honor, married again and again, "laris." The above statement can be identified that the bridal couple do not have the will to be a bride. But the bride do not have the power to fight the Ijab Kabul which is full of problems dilemmatic.

A resistance step of this marriage which is demonstrated by married briefly, then redefined the taboos about the divorce. "There are only two months, one month, one week, a day, it is quite good". The statement as a sign that has a meaning that women do not openly resisting the wedding procession. But secretly, the action postmarried women showed the resistance. The forms of resistance which is carried out is by staying married, but divorce immediately. It is an evidence that there has been resistance to the social norms of the marriage which is produced by the followers of patriarchy system.

Fifth narrative:

"Here, if you want to marry, you have to propose. The proposal is issued many pos- 
sessions. Which is capable of buying something until one truck. To be given into the people. But that is not capable if only mediocre, just a couple of buckets. After the gold. There is gold which has price until ten million, twenty million. So divorce is allowed. The price for the divorce is only one and a half million, that's enough. She will get the gold. If it is sold, more than ten million, there are twenty million, so it can be a profit thing. Proud. If you want to divorce, just register it, it's allowed. There is no shame here. Their daughters became a widow for few times, there is no shame. There are the proud parents. He gets many of the gold from many of the men.". (02.36 - 03.45 on the second video)

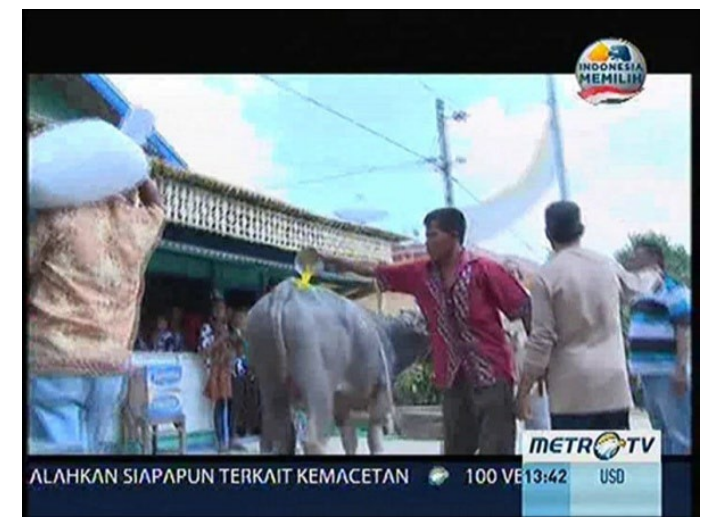

Gambar 7. Buffalo becomes a special thing which is brought by the groom when the proposal on the film scene "Dilema Ijab Kabul."

The resistance of the women in the movie "Dilema Ijab Kabul" without realizing there is a movement against the parents who marry and divorce their children in the young age. Women have to fight against the patriarchy system. The resistance has three targets at once in one action. The first resistance target is to their own parents. The second target is to their parents in-law. And the third target is their husbands.

The women who fight with his parents indicates their willingness to marry the man chosen by her parents. But after marriage, this young wife leaves her husband. The loyalty of the women to his parents only superficial. The women have played drama with the secret codes. The decision become a wife only one month, one week, even for just one day, is women's right. The women have the power in the form of freedom in deciding the divorce. They are no longer stuck in the glorious rule in which divorce is a failure to build a family. Obey the parents to marry with the chosen men by their parents, just a special gift which is full of falsity. It is like their daughters have fulfilled their parents' desire as their sacrifice in nurturing and educating. The first stage of this resistance, the women have succeeded in attacking their parents.

But the parents seem never be confronted, attacked, or betrayed by their daughters. Gain valuable things, has led the parents do not against their children. Moreover, the women's resistance has become a social class industry, where the girls who have been married and divorced repeatedly have given a respectable level of social class in the higher family.

The second target of women's resistance is the parents in-law. The process of proposing have been draining the ownership of the property from the prospective groom. "Which is capable of buying something such as a truck after the gold. There is gold which has price until ten million, twenty million." For the economic level of the communities who live on the slopes of the mountain, the things which are brought for the proposal are not the small things. Sell the livestock and a plot of land to get daughter in-law is a common thing. However, the valuable things just lost such as a blink of an eye, because the daughter in-law is no longer ignore the food and jewelery which is brought by their parents in-law.

In the tradition of patrilocal, women have become luxury item for the family of the groom. Because of the presence of the bride, will increase the level of production in the farm. This is a reason of why the family happily bring the snacks and gold in abundance when proposing their daughter in-law.

But the wish is vanished in the middle of the road. The women resistance to the patriarchy social system had locked the failure of the economic sustainability of the contract devotion to the family of the groom. 
In this position, the woman will more understand when she step on her foot in the groom family's house, it is the beginning of the exploitation. At that moment the parents in-law in the depressed condition of having lost possession in an instant.

So why do the parents in-law of the men constantly repeat the acts of wealth depletion? The reason is the parents in-law of the men also have daughters and granddaughters. They do not want their daughters or grandchildren will never be proposed by men in the future. From the process of this resistance, women look good at positioning themselves. A resistance strategy that looks weak, but it is proved to be stronger in the end the competition.

Then the third target of the resistance is a man who only has status as her husband in a couple days. This thing is needed to be noted is their social status after marriage between the men and women. In the movie "Dilema Ijab Kabul", women gain social status after marriage. Women who are married couple times are seen as valuable things. Getting married and then getting divorce repeatedly, as a sign that women have higher bargaining power because many men and parents in-law are interested to have the daughter in-law candidate to be in their family. But it is different with the men. The female does not have the valuable status after marriage. The widowers do not occupy exchanges appreciated social status. The reason is, there is no statement explaining why the inequality of the social status happens to men after the marriage. In terms of resistance, women won the battle and gradually undermine the patriarchy social system.

\section{Sixth narrative:}

"if I were young, I should be able to pursue my dreams. To be a useful person. Do not want to have early marriage. Because if you are married by the order of the parents, you are not able to go to school anymore, you can not. You should not be able to pursue your dreams". ( 02.55 - 03.31 On the third video)

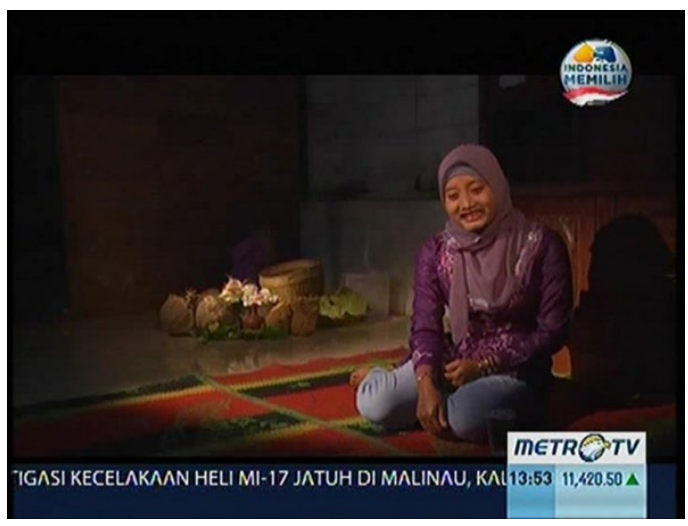

Picture 8. Solehantunnisak told her willingness to continue her study but, she was forced to marry by her parents on the film scene Dilema Ijab Kabul.

In the end of this documentary movie, there is something interesting about the admission of the girls towards the parents treatment in a match his at the young age. Direct statement that indicates that the women should be aware that the matchmaking and marrying too early is a heavy decision. But she did as filial piety towards the parents who embrace the patriarchy social system. The open transcript in a statement is these women want to reject the prevailing matchmaking structure. These women actually have to realize that by getting married in the young age, it is the same as eliminating their steps for schools to pursue their dreams in the future. This statement is also a collective reflection for the under-age generation of women in fighting this patriarchy system.

Based on the analysis of women's resistance against the patriarchy social system in Dilema Ijab Kabul, the motion pictures of the resistance can be mapped as follows. In the beginning, there is a definition of the game of the glory of a woman in the eyes of men. The definition of game in the form of social construction that unmarried women at the age of 16 is an old virgin. The definition is transformed into a trap of meaning. This definition has engineered itself that women exploit themselves by releasing the pure virgin status, in order to pursue a social status that is equivalent to the power of the men.

This part becomes a preliminary pictu- 
re of their interests and the power of a group of men. Interest and power which have tied the women through the use of symbols of the tradition that later ensnare the woman mind. The mind that has ensnared makes women no longer powerless in carrying out the wedding procession.

After the women are bound to obey the order which is produced by the patriarchy social system, then it is time to harvest the luck of the game. The adherents of this patriarchy system have been harvested through the procession of the wedding celebration. Wedding celebration has been exploited in such a way. The function of the wedding celebration has been moving rapidly as if to leave the function of a wedding procession in general. It can be seen that the procession of celebration has become a social class performances. In addition, the wedding procession has function to be instrumental in collecting the donations so, after the wedding celebration there is substitute for the cost of the wedding.

To keep the adherents of the patriarchy power at the top, they fortify themselves with the meaning of a matchmaking, marriage, and divorce. Matchmaking has been reproduced as a social status. They look at each other, when the matchmaking end into a divorce, it is not a failure. Being a widow is seen has raised the status of the women. From the description above, it appears a definition of a marriage and matchmaking which have been run.

But behind the interests and the power of patriarchy system in the documentary film Dilema Ijab Kabul, the women do not stay silent. Indeed, the women are powerless in lifting their bodies from the forced matchmaking process. The resistance of the women indicated by the movement of divorcing themselves from the sacred marriage. Behind the divorce which has the function of economic and honor, it turns to be an instrument in divorce against the patriarchy system which has been grounded.

The women want to win the men's game. Once against, the women has three targets at once. Parents, parents in-law, and husband as the good target. Their obedience to their parents is only apparent. Their marriage has been draining their parents property. And the status of the divorced never exist in an social honor.

The women have played a two-faced power on the stage. But from the resistance, they do not realize that they have played in this role. It can be seen that there is a transcript of open women resistance to the patriarchy system is divorce. And the hidden transcript is rejecting an arranged marriage and married at a young age. The documentary film Dilema Ijab Kabul has explained how the resistance of women against the patriarchy system.

\section{CONCLUSION}

The film of Dilemma Ijab Kabul has a resistance attraction which does not exist in the previous films. If the previous films tend to show the resistance of the women by means of awareness that women in marginalized positions, based on the above study it was clear that women have surpassed the limit which is indicated by the social power into the owner of the power system who brave to perform the movement without hesitation in breaking the walls of the patriarchy system.

The power of the women in the film "Dilema Ijab Kabul" is indicated with the decision to decide the divorce, the result of the forced marriage from the patriarchy system. With the power, the women immediately held the marriage many times, that every marriage always get a lot of material from the proposal procession. The power of female resistance towards the patriarchy system which is done by the women in this documentary film have comparable proportionate to the amount phenomenon of early marriages, divorce and remarried. Divorce and remarried in the film "Dilema Ijab $\mathrm{Ka}$ bul" is a form of women resistance from the forced marriages by the patriarchy system. Thus the higher the hegemonic patriarchy system towards the women, the elevating struggle of women towards the patriarchy system. 


\section{REFERENCES}

Anonim. 2014. Rating Report. Dalam allaboutdiniatv. blogspot.com/2014/o6/rating-report-cacatanhati-seorang.html. Diakses pada tanggal 14 Agustus 2014.

BBC. 2014. Perempuan Kurang Terwakili Dalam Film. Dalam http://www.bbc.co.uk/indonesia/majalah/2014/o3/140311_hiburan_perempuan. shtml. Diakses pada tanggal 17 Agustus 2014.

De Haas, H. and Van Rooij, A., 2010. Migration as emancipation? The impact of internal and international migration on the position of women left behind in rural Morocco. Oxford development studies, 38(1), pp.43-62.

Edgar, A., 2006. Bolshevism, patriarchy, and the nation: The Soviet "emancipation" of Muslim women in Pan-Islamic perspective. Slavic Review, 65(2), pp.252-272.

Fakih, M., 2006. Analisis Gender dan Transformasi Sosial. Pustaka Pelajar, Yogyakarta.

Ghassani, H., 2010. Kekerasan Terhadap Perempuan: Analisis Semiotika Film Jamila dan Sang Presiden. Undergraduate Thesis. UNDIP, Semarang.

Ghodsee, K., 2012. Rethinking State Socialist Mass Women's Organizations: The Committee of the Bulgarian Women's Movement and the United Nations Decade for Women, 1975-1985. Journal of Women's History, 24(4), pp.49-73.

Henslin, J.M., 2006. Sosiologi Dengan Pendekatan Membumi: Edisi 6. Erlangga, Jakarta.

Hunnicutt, G., 2009. Varieties of patriarchy and violence against women: Resurrecting "patriarchy" as a theoretical tool. Violence against women, 15(5), pp.553-573.

Mir-Hosseini, Z., 2006. Muslim women's quest for equality: Between Islamic law and feminism. Critical inquiry, 32(4), pp.629-645.

Moghadam, V.M., 2004. Patriarchy in transition: Women and the changing family in the Middle East. Journal of Comparative Family Studies, pp.137-162.

Muslim, B. 2009. Makna Perkawinan Dalam Film (Analisis Semiotik pada Film "Get Married" Karya Musfar Yasin). Undergraduate Thesis. Universitas Muhammadiyah Malang, Malang.

Neuendorf, K.A. 2002. The Content Analysis Guide- book Online. Retrieve http://academic.scuohio.edu/kneuendorf/content/. 14 Agustus 2014.

Prismadani, C.A., 2011. Mitos Keluarga Muslim dalam Sinetron Inayah: Analisis Semiotika terhadap Sinetron Inayah. Research Report. UNDIP, Semarang.

Razack, S.H., 2004. Imperilled Muslim women, dangerous Muslim men and civilised Europeans: Legal and social responses to forced marriages. Feminist legal studies, 12(2), pp.129-174.

Risambessy, M.S. 2011. Representasi Perempuan Berpenampilan Maskulin dalam Film Get Married (Studi Semiotika Representasi Perempuan Berpenampilan Maskulin dalam Film Get Married). Undergraduate Thesis. Universitas Pembangunan Nasional, Surabaya.

Salhi, Z.S., 2010, April. The Algerian feminist movement between nationalism, patriarchy and Islamism. Women's Studies International Forum, 33(2), pp. 113-124.

Smith-Hefner, N.J., 2005. The new Muslim romance: Changing patterns of courtship and marriage among educated Javanese youth. Journal of Southeast Asian Studies, 36(3), p.441.

Suhadi. 2010. Penelitian Sosial: Suatu Perspektif Awal Untuk Peneliti Pemula. Smapamedia, Rembang.

Suhadi. 2011. Kartini dalam Pusaran Feminisme Indonesia: Studi Kritis Tentang Perempuan dan Pembangunan Indonesia. Program Pascasarjana, Universitas Negeri Semarang, Semarang.

Suhadi. 2012. Pernikahan Dini, Perceraian, dan Pernikahan Ulang. Jurnal Komunitas, 4(2), pp.168177 .

Surwati, C.H.D. 2011. Konstruksi Feminisme dalam Film Indonesia (Analisis Wacana Kritis Konstruksi Feminisme dalam Film Indonesia Karya Sutradara Nia Dinata). Universitas Sebelas Maret Surakarta, Surakarta.

Tong, R.P. 1998. Feminist Thought: Pengantar Paling Komprehensif kepada Aliran Utama Pemikiran Feminis. Jalasutra, Yogyakarta.

Wikipedia. 2014. Cacatan Hati Seorang Istri. Retrieve http://id.m.wikipedia.org/wiki/catatan_hati_ seorang_istri.html. 14 August 2014. 